\title{
Macrolide antibiotics inhibit nitric oxide generation by rat pulmonary alveolar macrophages
}

\author{
K. Kohri, J. Tamaoki, M. Kondo, K. Aoshiba, E. Tagaya, A. Nagai
}

\begin{abstract}
Macrolide antibiotics inhibit nitric oxide generation by rat pulmonary alveolar macrophages. K. Kohri, J. Tamaoki, M. Kondo, K. Aoshiba, E. Tagaya, A. Nagai. (C) ERS Journals Ltd 2000.

ABSTRACT: There is evidence that macrolide antibiotics are effective in the treatment of chronic airway inflammatory diseases, probably through actions other than their antibacterial properties.

In order to determine whether macrolides affect the nitric oxide-generating system in the respiratory tract, rat pulmonary alveolar macrophages (PAMs) were studied in vitro. The release of $\mathrm{NO}$ was assessed by direct measurement with a specific amperometric sensor for this molecule, and the expression of type II NO synthase (NOS) messenger ribonucleic acid (mRNA) was determined by Northern blotting.

Incubation of PAMs with lipopolysaccharide from Escherichia coli and recombinant human interferon-gamma caused release of NO, which was accompanied by induction of type II NOS mRNA. The release of NO was reduced by coincubation of cells with the macrolides erythromycin, clarithromycin and josamycin in a concentration-dependent manner, the maximal inhibition being $73 \pm 10,81 \pm 6$ and $84 \pm 9 \%$, respectively, but was not altered by amoxycillin or cefaclor. These macrolides likewise inhibited the induction of type II NOS mRNA, whereas no inhibitory effects were observed with amoxycillin or cefaclor.

These results suggest that macrolide antibiotics specifically inhibit type II NO synthase gene expression and consequently reduce NO production by rat pulmonary alveolar macrophages, which might result in attenuation of airway inflammation. Eur Respir J 2000; 15: 62-67.
\end{abstract}

First Dept of Medicine, Tokyo Women's Medical University School of Medicine, Tokyo, Japan.

Correspondence: J. Tamaoki, First Dept of Medicine, Tokyo Women's Medical University School of Medicine, 8-1 KawadaCho, Shinjuku, Tokyo 162-8666, Japan, Fax: 81353795457

Keywords: Airway inflammation erythromycin

nitric oxide synthase

polarography

transcription

Received: June 251999

Accepted after revision October 181999

This work was supported, in part, by Grant-in-Aid No. 06670243 and 09770429 from the Ministry of Education, Science and Culture, Japan.
Nitric oxide is a highly reactive gaseous free radical generated from the amino acid L-arginine by NO synthase (NOS), which exists in both constitutive and inducible isoforms [1, 2]. Endogenous NO may be involved in the regulation of airway and vascular smooth muscle tone, microvascular permeability, pulmonary neurotransmission and host defence [3]. Moreover, NO may have antiinflammatory effects, such as protection against vascular leakage, leukocyte adherence and cellular damage [4, 5]. However, NO can exert deleterious effects when it is inappropriately generated or overproduced, and excessive amounts of NO and its metabolites such as peroxynitrite may contribute to the pathophysiology of inflammation and the resultant tissue damage $[3,6,7]$. In the respiratory tract, the existence of constitutive form of NOS (type I and type III NOS) has been shown in various cell types, including vascular endothelial cells, nerve cells and airway epithelial cells [8], indicating that these cells constitutively generate NO. Conversely, production of NO is upregulated in a variety of pulmonary inflammatory diseases [9-11], in which inducible NOS (type II NOS) in pulmonary alveolar macrophages (PAMs) may be involved.

There is some evidence to suggest that long-term administration of the macrolide antibiotic agent erythromycine may be effective in the treatment of chronic airway inflammation, including chronic bronchitis, bronchiectasis and diffuse panbronchiolitis $[12,13]$. Although the mechanisms are uncertain, macrolides may exert these effects through actions other than their antimicrobial properties, such as immunomodulatory actions on inflammatory cells [13], reduction of airway secretion [14] and inhibition of cholinergic neurotransmission [15]. Because overproduction of NO by type II NOS may be associated with the development of airway inflammation, it was hypothesized that macrolides could affect the NO-generating system in inflammatory cells. Therefore, in the present study, the effects of macrolides and other antibiotics on the release of NO from rat PAMs by means of real-time measurement of NO levels using a highly specific amperometric sensor for this molecule and on the expression of the type II NOS gene by Northern blot analysis were examined.

\section{Materials and methods}

Isolation and culture of rat pulmonary alveolar macrophages

Pathogen-free Sprague-Dawley rats weighing 300-350 $\mathrm{g}$ were anaesthetized with intraperitoneal sodium pentobarbital $\left(40 \mathrm{mg} \cdot \mathrm{kg}\right.$ body weight $\left.{ }^{-1}\right)$ and sacrificed by cutting the abdominal aorta. Bronchoalveolar lavage cells were collected by lavaging whole lungs with five instillations of $10 \mathrm{~mL}$ saline via a tracheal canula and withdrawing the fluid slowly while gently massaging the thorax. The lavage cells were pelleted by centrifugation $(10 \mathrm{~min}, 200 \times g)$, washed twice with phosphate-buffered saline and resuspended in RPMI-1640 medium. More than $95 \%$ of the 
cells in this preparation were PAMs, as determined morphologically by May-Giemsa staining. Their viability was $>95 \%$, as determined by trypan blue exclusion. The PAMs were adjusted to $10^{6}$ cells $\cdot \mathrm{mL}^{-1}$ with RPMI-1640 medium containing $10 \%$ heat-inactivated foetal bovine serum, penicillin $\left(50 \mathrm{U} \cdot \mathrm{mL}^{-1}\right)$ and streptomycin $\left(50 \mu \mathrm{g} \cdot \mathrm{mL}^{-1}\right)$, and seeded on $60-\mathrm{mm}$-diameter plastic culture dishes. After incubation in 5\% carbon dioxide $/ 95 \%$ air at $98 \%$ relative humidity for $120 \mathrm{~min}$ at $37^{\circ} \mathrm{C}$, nonadherent cells were removed by aspiration. The adherent cells were cultured with $4 \mathrm{~mL}$ serum-free RPMI-1640 medium and stimulated for $12 \mathrm{~h}$ with lipopolysaccharide (LPS) from Escherichia coli $\left(50 \mathrm{ng} \cdot \mathrm{mL}^{-1}\right)$ and recombinant human interferon gamma (IFN- $\gamma, 50 \mathrm{U} \cdot \mathrm{mL}^{-1}$ ) in the presence of various concentrations of erythromycin, clarithromycin, josamycin, amoxycillin, cefaclor or dexamethasone. In the control experiment, the cells were incubated for $12 \mathrm{~h}$ with the culture medium containing the vehicle of the drug (sterile saline) alone. A preliminary experiment showed that the PAMs incubated for $12 \mathrm{~h}$ with LPS and IFN- $\gamma$ consistently showed positive staining for type II NOS-like immunoreactivity, the final concentration of PAMs in the culture medium was $6.6 \pm 1.2 \times 10^{5}$ cells $\cdot \mathrm{mL}^{-1}(\mathrm{n}=16)$, and there were no significant differences in the number of PAMs between control, cytokine-treated, antibiotic-treated and dexamethasone-treated groups.

\section{Measurement of nitric oxide release}

The concentration of NO in the medium containing cultured PAMs was determined using an NO meter (Model NO-501; Inter Medical Co., Tokyo, Japan) by measuring the redox current between the following two electrodes [16]. The counter electrode was made of carbon fibre, and the NO-selective working electrode of platinum/iridium alloy $(0.2 \mathrm{~mm}$ in diameter; Pt $90 \%$, Ir $10 \%)$ coated with a three-layered membrane that consisted of potassium chloride, NO-selective resin and normal silicone membranes. The working electrode was supplied with $0.4-0.8 \mathrm{~V}$ for the electrochemical oxidization of NO. The NO diffusing through the membrane was detected as an electrical current based on the following reaction: $\mathrm{NO}+2 \mathrm{H}_{2} \mathrm{O} \rightarrow$ $\mathrm{NO}_{3}{ }^{-}+4 \mathrm{H}^{+}+3$ electrons. The current flow was proportional to the rate of diffusion through the membrane, which was, in turn, proportional to the concentration of $\mathrm{NO}$ at the outer surface of the membrane.

Before and after the 12-h incubation of PAMs with LPS and IFN- $\gamma$, the working electrode and counter electrode were placed $5 \mathrm{~mm}$ apart in the medium, and L-arginine $\left(10^{-3} \mathrm{M}\right)$ was added. The response of polarographic current was detected by a current/voltage converter circuit and continuously recorded for $2 \mathrm{~h}$ on a chart recorder (Model SR-6355; Graphtec, Tokyo, Japan).

Calibration of the electrodes was performed daily prior to experiments. It is known that the nitrosothiol NO donor $S$-nitroso- $N$-acetyl-DL-penicillamine (SNAP) decomposes and generates NO in solution, and that the concentration of $\mathrm{NO}$ in this solution is constant ([NO] $\left.10^{-3} \times[\mathrm{SNAP}]\right)$ as long as both temperature and oxygen concentration are constant $[16,17]$. Thus, using SNAP as a standard, the relationship between the magnitude of the electrical current and the concentration of SNAP in the medium was determined. The current increased linearly as SNAP concentration increased (fig. 1); thus the concentration of NO could be determined from the electrical current recorded. Addition of heat-decomposed SNAP produced only $2 \%$ of the original current, and oxyhaemoglobin $\left(4 \times 10^{-6}\right.$ M) and 2-phenyl-4,4,5,5-tetramethylimidazole-3-oxide1-oxyl (PTIO, $3 \times 10^{-5} \mathrm{M}$ ) suppressed the current produced by $5 \times 10^{-5} \mathrm{M}$ SNAP. Thus, there was no significant direct effect of SNAP itself on the electrical current. Moreover, immersion of the electrode in the medium containing L-arginine $\left(10^{-3} \mathrm{M}\right)$ and each macrolide $\left(10^{-4} \mathrm{M}\right)$ but not PAMs was without effect on the current, indicating that these drugs per se had no effect on the electrode.

\section{Northern blotting}

Total ribonucleic acid (RNA) was extracted from cultured PAMs $12 \mathrm{~h}$ after LPS and IFN- $\gamma$ stimulation by means of the guanidinium/phenol/chloroform method. The total RNA $(2.5 \mu \mathrm{g})$ was fractionated via $1 \%$ formaldehyde/ agarose gel electrophoresis, transferred to nylon membranes (Hybond N+, Amersham, UK) and immobilized with ultraviolet cross-linking.

A rat type II NOS partial complementary deoxyribonucleic acid (cDNA) probe (685 base pairs (bp)) was prepared by means of the reverse transcriptase polymerase chain reaction (PCR). RNA prepared from PAMs was reverse transcribed into cDNA, and PCR performed to amplify the 685-bp cDNA fragment. The sequences of the forward (5'-GAGATCAATGCAGCTGTG-3') and reverse (5'-GCTTCTGGTCGATGTCATGAGCAA-3') primers were based on the published type II NOS cDNA sequence $[18,19]$. The authenticity of the PCR products was confirmed via dideoxy sequencing methods. The cDNA probe for human $\beta$-actin was purchased from Clonetech (Palo Alto, CA, USA).

The probes for rat type II NOS and human $\beta$-actin were labelled with $\left[\alpha_{-}{ }^{32} \mathrm{P}\right]$ deoxycytidine triphosphate (Amersham) using a random prime labelling method. Then hybridization and autoradiography were performed. In all experiments, the values obtained by densitometric scanning of the blots hybridized with the probe for type II NOS were corrected using the values obtained from hybridization with the $\beta$-actin probe.

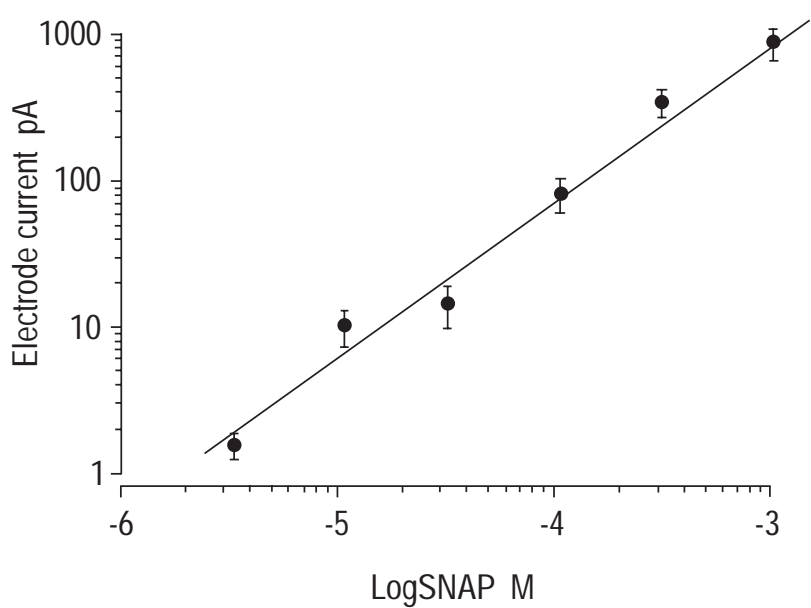

Fig. 1. - Relationship between the concentration of $S$-nitroso- $N$-acetylDL-penicillamine (SNAP) in RPMI-1640 medium at $37^{\circ} \mathrm{C}$ and the current detected by a nitric oxide-selective electrode. Data are presented as mean \pm SEM; $n=18-21$ for each point. 


\section{Reagents}

The following drugs were used: LPS from E.coli, Larginine, erythromycin, dexamethasone, aminoguanidine (Sigma Chemical Co., St Louis, MO, USA); recombinant human IFN- $\gamma$ (Otsuka Pharmaceutical Co., Tokyo, Japan); clarithromycin (Taisho Pharmaceutical Co., Tokyo, Japan); josamycin (Yamanouchi Pharmaceutical Co., Tokyo, Japan); amoxycillin (Takeda Pharmaceutical Industries, Osaka, Japan); cefaclor (Shionogi Pharmaceutical Co., Osaka, Japan); SNAP (Inter Medical Co., Tokyo, Japan); and PTIO (Tokyo Kasei Kogyo Co., Tokyo, Japan). Oxyhaemoglobin was prepared by reducing bovine haemoglobin (Sigma) using sodium dithionite and purified on a Sephadex G-25 column (Pharmacia, Uppsala, Sweden).

\section{Statistical analysis}

All data are expressed as mean \pm SEM. Statistical analysis was performed by analysis of variance or the NewmanKeul multiple comparison test, and a p-value of $<0.05$ was considered statistically significant.

\section{Results}

\section{Release of nitric oxide}

The rat PAMs were incubated for $12 \mathrm{~h}$ before $\mathrm{L}$-arginine was added. The output current of the NO-selective electrode in the medium bathing the cultured PAMs is demonstrated in figure 2. Immersion of the electrode in the medium did not produce electrical current in PAMs that had been incubated with the solvent of LPS and IFN- $\gamma$ (saline) alone, even in the presence of L-arginine $\left(10^{-3} \mathrm{M}\right)$ (fig. 2a). When the cells were incubated with LPS (50 $\left.\mathrm{ng} \cdot \mathrm{mL}^{-1}\right)$ plus IFN- $\gamma\left(50 \mathrm{U} \cdot \mathrm{mL}^{-1}\right)$, baseline current was not detected, but application of L-arginine caused an increase in the current with a lag time of $10 \mathrm{~s}-3 \mathrm{~min}$. Between 15 and $30 \mathrm{~min}$ after the addition of L-arginine, the response showed the maximal value of $147 \pm 25 \mathrm{pA}$ $(\mathrm{p}<0.001, \mathrm{n}=11)$, which corresponds to an NO concentration of $116 \pm 20 \mathrm{nM}$ in the medium [16], and the subsequent electrical current remained elevated during a $2-\mathrm{h}$ observation period (fig. 2b). To assess whether the observed response was associated with type II NOSmediated release of $\mathrm{NO}$, after the response of electrical current reached a plateau, aminoguanidine $\left(10^{-5} \mathrm{M}\right)$, a specific inhibitor of NO synthesis through type II NOS [20], was added to the medium. As shown in figure 2c, addition of aminoguanidine rapidly decreased the current by $76 \pm 9 \%(\mathrm{p}<0.001, \mathrm{n}=9)$ in PAMs treated with LPS plus IFN- $\gamma$.

The rat PAMs were incubated for $12 \mathrm{~h}$ with LPS plus IFN- $\gamma$ in the presence of erythromycin $\left(10^{-7}-10^{-4} \mathrm{M}\right)$, clarithromycin $\left(10^{-7}-10^{-4} \mathrm{M}\right)$, josamycin $\left(10^{-7}-10^{-4} \mathrm{M}\right)$, amoxycillin $\left(10^{-4} \mathrm{M}\right)$, cefaclor $\left(10^{-4} \mathrm{M}\right)$ or dexamethasone $\left(10^{-7} \mathrm{M}\right)$. As shown in figure $2 \mathrm{~d}$ and figure 3 , exposure of cells to erythromycin, clarithromycin or josamycin at $10^{-4}$ $\mathrm{M}$ reduced the electrical current induced by LPS plus IFN $-\gamma$ by $73 \pm 10,81 \pm 6 \%$, or $84 \pm 9 \%$, respectively ( $p<$ $0.001, \mathrm{n}=11$ for each drug). Dexamethasone $\left(10^{-7} \mathrm{M}\right)$ likewise inhibited the production of NO by $96 \pm 4 \%(\mathrm{p}<$ $0.001, \mathrm{n}=11$ ), but amoxycillin and cefaclor at $10^{-4} \mathrm{M}$ had no effect. The inhibitory effects of the macrolide antibiotics on NO release were dose-dependent, the concen- a)

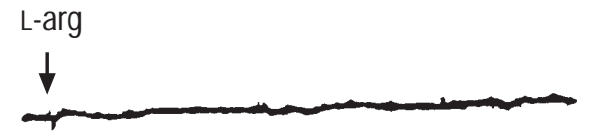

b)

c)

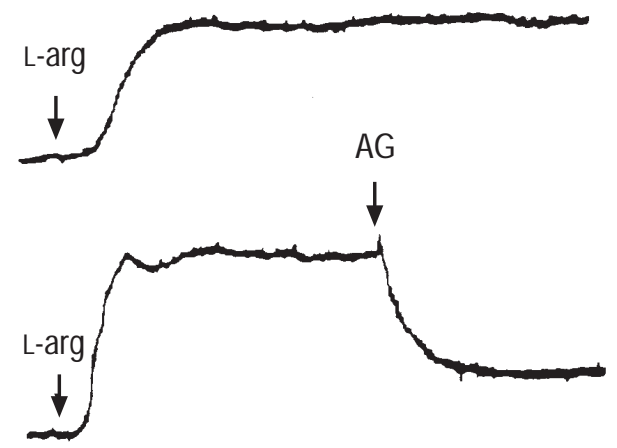

d)

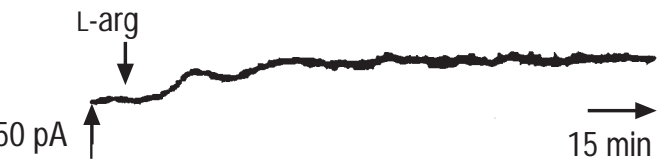

Fig. 2. - Representative traces of the current detected by an NO-selective electrode in RPMI-1640 medium containing rat pulmonary alveolar macrophages (PAMs). After equilibration, L-arginine (L-Arg, $\left.10^{-3} \mathrm{M}\right)$ was added to the medium (arrows). a) Response of the electrical current in the medium containing unstimulated PAMs (control). b, c) PAMs were incubated for $12 \mathrm{~h}$ in the presence of lipopolysaccharide (LPS, 50 $\mathrm{ng} \cdot \mathrm{mL}^{-1}$ ) and interferon gamma (IFN- $\left.\gamma, 50 \mathrm{U} \cdot \mathrm{mL}^{-1}\right)$. When the response reached a plateau, aminoguanidine (AG, $10^{-5}$ ) was added. d) PAMs were incubated for $12 \mathrm{~h}$ in the presence of LPS, IFN- $\gamma$ and clarithromycin $\left(10^{-4}\right)$

tration of drug required to reduce the NO concentration bt $50 \%$ being $5.1 \pm 1.2 \times 10^{-6} \mathrm{M}$ for erythromycin, $3.8 \pm 0.9$ $\times 10^{-6} \mathrm{M}$ for clarithromycin and $1.4 \pm 1.1 \times 10^{-5} \mathrm{M}$ for josamycin ( $\mathrm{n}=8$ for each) (fig. 4).

\section{Type II nitric oxide synthase gene expression}

In order to evaluate the effects of macrolide antibiotics on type II NOS gene expression, Northern blot analysis was performed on total RNA isolated from cultured PAMs. The PAMs were incubated for $12 \mathrm{~h}$ with LPS $\left(50 \mathrm{ng} \cdot \mathrm{mL}^{-1}\right)$ plus IFN- $\gamma\left(50 \mathrm{U} \cdot \mathrm{mL}^{-1}\right)$ in the absence or presence of each antibiotic agent or dexamethasone. Total RNA was then extracted and analysed by means of Northern blotting with type II NOS and $\beta$-actin cDNA probes. Three distinct nucleic acid bands were observed in the hybridization for type II NOS, as reported previously [21, 22]. The most prominent, 4.4 kilobase transcript is shown in figure 5. When the cells were treated with LPS plus IFN- $\gamma$, a marked increase in the steady-state level of type II NOS messenger (RNA) was observed. This induction of type II NOS mRNA expression was inhibited by coincubation with $10^{-4} \mathrm{M}$ erythromycin (66\% inhibition), $10^{-4} \mathrm{M}$ clarithromycin $(80 \%), 10^{-4} \mathrm{M}$ josamycin $(79 \%)$ and $10^{-7} \mathrm{M}$ dexamethasone (97\%) (fig. 5a). Clarithromycin inhibited type II NOS gene expression in a dose-dependent manner (figs. 5a and 6), whereas no inhibitory effects were observed with amoxycillin or cefaclor (figs. $5 \mathrm{c}$ and 6). 


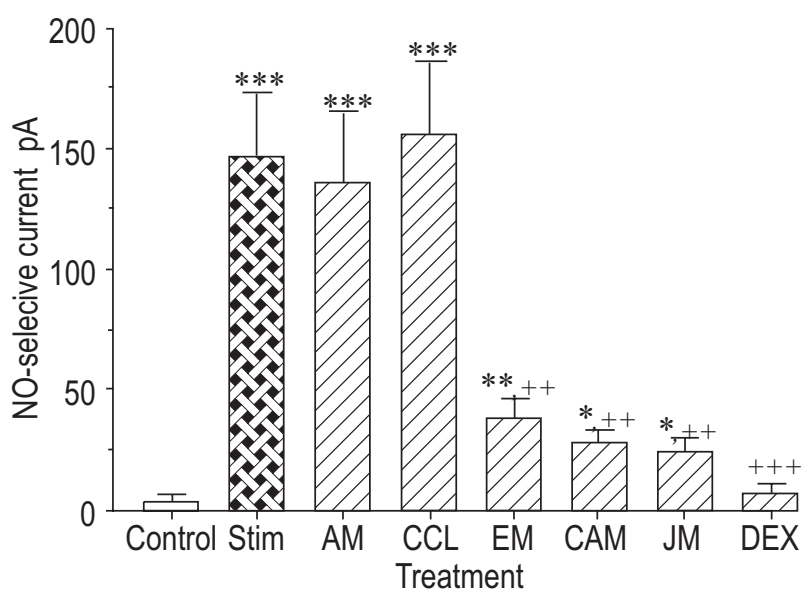

Fig. 3. - Effects of antibiotics and a steroid on the production of NO from rat pulmonary alveolar macrophages (PAMs) stimulated with lipopolysaccharide (LPS, $50 \mathrm{ng} \cdot \mathrm{mL}^{-1}$ ) and interferon gamma (IFN- $\gamma, 50$ $\left.\mathrm{U} \cdot \mathrm{mL}^{-1}\right)$ (stim). The PAMs were incubated for $12 \mathrm{~h}$ in the absence and presence of amoxycillin (AM, $\left.10^{-4} \mathrm{M}\right)$, cefaclor $\left(\mathrm{CCL}, 10^{-4} \mathrm{M}\right)$, erythromycin (EM, $\left.10^{-4} \mathrm{M}\right)$, clarithromycin $\left(\mathrm{CAM}, 10^{-4} \mathrm{M}\right)$, josamycin (JM, $\left.10^{-4} \mathrm{M}\right)$ or dexamethasone $\left(\mathrm{DEX}, 10^{-7} \mathrm{M}\right)$. Values represent the maximal response of the NO-selective current in the culture medium after addition of L-arginine $\left(10^{-3} \mathrm{M}\right)$. Data are presented as mean \pm SEM; $\mathrm{n}=11$ for each column. $*$ : $\mathrm{p}<0.05 ; * *: \mathrm{p}<0.01 ; * * *: \mathrm{p}<0.001$ versus unstimulated PAMs (control). ${ }^{++}: \mathrm{p}<0.01 ;{ }^{++}: \mathrm{p}<0.001$ versus LPS plus IFN- $\gamma$ alone.

\section{Discussion}

The present in vitro studies demonstrate that the expression of the type II NOS gene and release of NO by rat PAMs are induced by LPS and IFN- $\gamma$, and that these effects can be inhibited by macrolide antibiotics. The inhibition of $\mathrm{NO}$ generation by macrolides might be associated with their anti-inflammatory actions in the respiratory tract.

Based on molecular cloning and sequencing analyses, there are at least three main isoforms of NOS [1]: type I (primarily soluble, e.g., in brain); type II (primarily soluble, e.g. in macrophages) and type III (primarily parti-

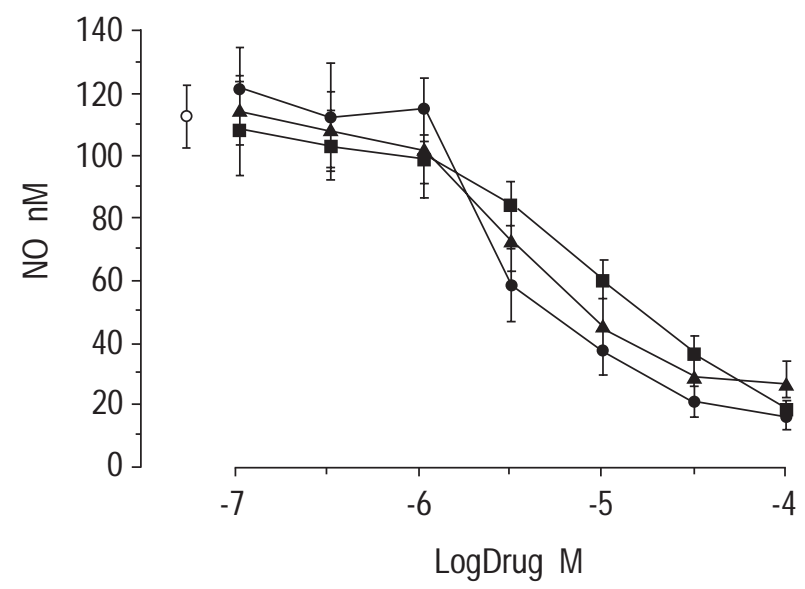

Fig. 4. - Dose dependent effects of macrolide antibiotics on the release of NO from rat pulmonary alveolar macrophages (PAMs) stimulated with lipopolysaccharide (LPS, $50 \mathrm{ng} \cdot \mathrm{mL}^{-1}$ ) and interferon gamma (IFN$\gamma, 50 \mathrm{U} \cdot \mathrm{mL}^{-1}$ ). The PAMs were incubated for $12 \mathrm{~h}$ with LPS plus IFN- $\gamma$ either alone $(O)$ or in combination with various concentrations of erythromycin $(\mathbf{\Delta})$, clarithromycin $(\bullet)$ or josamycin $(\boldsymbol{\square})$. Values represent the concentration of $\mathrm{NO}$ in the culture medium after addition of L-arginine $\left(10^{-3} \mathrm{M}\right)$. Data are presented as mean \pm SEM; $n=8$ for each point. a) C stim EM CAM JM DEX
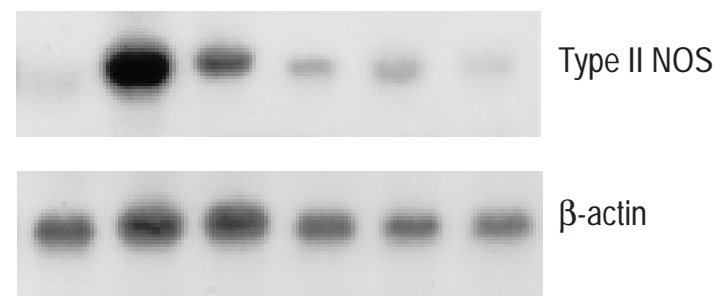

b)
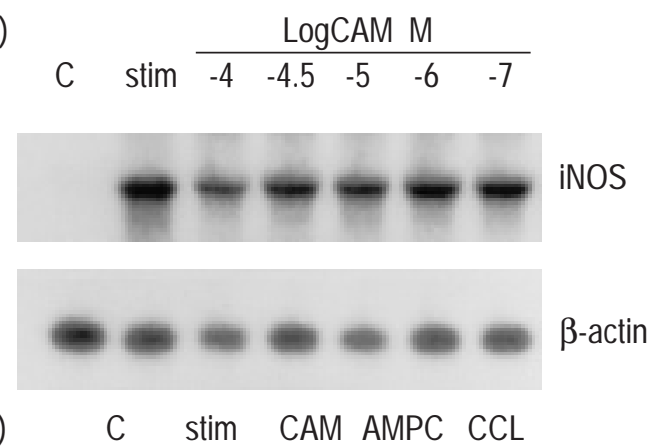

c)

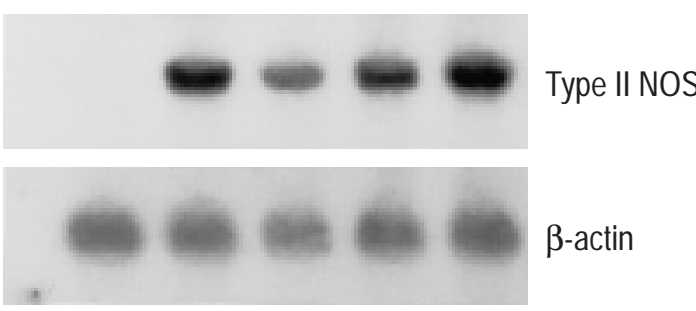

Fig. 5. - Effects of antibiotics and a steroid on type II nitric oxide synthase (NOS) (inducible NOS) messenger ribonucleic acid (RNA) expression by rat pulmonary alveolar macrophages (PAMs) stimulated with lipopolysaccharide $\left(50 \mathrm{ng} \cdot \mathrm{mL}^{-1}\right)$ and interferon gamma $(50$ $\left.\mathrm{U} \cdot \mathrm{mL}^{-1}\right)$ (stim). In the control (C) experiment, PAMs were treated with saline alone. Total RNA $(2.5 \mu \mathrm{g})$ was isolated after a 12-h incubation, and a Northern blot performed with type II NOS and $\beta$-actin complementary deoxyribonucleic acid probes. Three distinct nucleic acid bands were observed in the hybridization for type II NOS as reported previously, and the most prominent, 4.4-kilobase, band is shown. a) Effects of erythromycin (EM), clarithromycin (CAM), josamycin (JM) at $10^{-4} \mathrm{M}$ and dexamethasone (DEX) at $10^{-7} \mathrm{M}$; b) Concentrationdependent effects of CAM; c) Effects of CAM, amoxycillin (AMPC) and cefaclor (CCL) at $10^{-4} \mathrm{M}$.

culate, e.g. in endothelium). Compared with type I and type III NOS, which require $\mathrm{Ca}^{2+}$ and calmodulin for enzyme activation, type II NOS may spontaneously synthesize and release NO, once it is induced [23]. However, it has not been known how much NO is released from type II NOS-containing cells. In this study, NO release from rat PAMs was measured using an NO-selective electrode $[16,24]$. Even when the electrode was immersed in medium containing PAMs which had been incubated with LPS and IFN- $\gamma$, no current was detected. Although the concentration of L-arginine in the medium after the 12-h incubation period was not measured, the failure to detect NO might be due to depletion of L-arginine, a substrate of NOS, during the incubation, since addition of L-arginine caused an increase in the NO-selective current. Indeed, JORENS et al. [25] showed that the production of nitrite by rat PAMs required the presence of L-arginine in the culture medium. It was also found that the subsequent addition of aminoguanidine, a specific inhibitor of type 


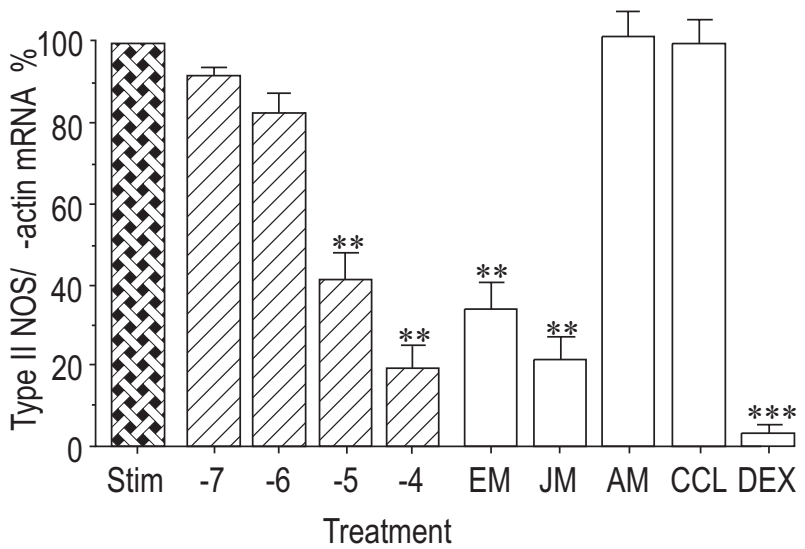

Fig. 6. - Effects of antibiotics and a steroid on type II nitric oxide synthase (NOS) messenger ribonucleic acid (mRNA) expression by rat pulmonary alveolar macrophages (PAMs) stimulated with lipopolysaccharide (LPS, $50 \mathrm{ng} \cdot \mathrm{mL}^{-1}$ ) and interferon gamma (IFN- $\gamma, 50 \mathrm{U} \cdot \mathrm{mL}^{-1}$ ) (stim). The PAMs were incubated in the absence and presence of clarithromycin (CAM, 10 $\left.10^{-7}-10^{-4} \mathrm{M}\right)$, erythromycin (EM, $\left.10^{-4} \mathrm{M}\right)$, josamycin $\left(\mathrm{JM}, 10^{-4} \mathrm{M}\right)$, amoxycillin $\left(\mathrm{AM}, 10^{-4} \mathrm{M}\right.$ ), cefaclor (CCL, $10^{-4}$ $\mathrm{M})$ or dexamethasone (DEX, $\left.10^{-7} \mathrm{M}\right)$. The mRNA levels of independently performed experiments were quantified by densitometric scanning, normalized for the corresponding $\beta$-actin signals and expressed as a percentage of those obtained for LPS plus IFN- $\gamma$. Data are presented as mean \pm SEM; $\mathrm{n}=4-6 .{ }^{*}: \mathrm{p}<0.05 ; * *: \mathrm{p}<0.01 ; * * *: \mathrm{p}<0.001$ versus LPS plus IFN- $\gamma$ alone.

II NOS [20], reduced the current, indicating that the observed production of NO was type II NOS-mediated. This notion was further confirmed by the corresponding induction of type II NOS mRNA by stimulation with LPS plus IFN- $\gamma$.

In contrast to rat PAMs, the existence of type II NOS in human PAMs has been controversial. Although there is indirect evidence for the expression of type II NOS in human PAMs [26], many laboratories have had difficulties in inducing human PAMs to express this protein in vitro [27, 28]. Recent studies have shown that strong immunoreactivity can be detected with the anti-type II NOS antibody in PAMs from patients with bronchiectasis, acute bronchopneumonia and pulmonary tuberculosis but not from normal subjects $[29,30]$. These data indicate that human PAMs are also capable of expressing type II NOS, and probably of producing NO under certain conditions. There is evidence that the concentration of NO in exhaled air is increased in patients with asthma [9] and bronchiectasis [11], and that long-term administration of erythromycin or clarithromycin may be clinically effective in the treatment of chronic bronchitis, bronchiectasis and diffuse panbronchiolitis [12, 13]. The efficacy of these macrolide antibiotics may not be accounted for by their antimicrobial properties but rather by antisecretory and/or anti-inflammatory actions. For example, macrolides inhibit the accumulation of neutrophils in the airways [31], generation of reactive oxygen species by neutrophils [32], release of tumour necrosis factor- $\alpha$ from PAMs [33] and interleukins-6 and 8 from bronchial epithelium [34] and expression of endothelin-1 in bronchial epithelial cells [35]. In addition, the present experiments show that macrolides decrease NO production from PAMs. These effects may lead to the suppression of airway inflammatory responses. In fact, SATO et al. [36] have recently shown that erythromycin attenuates virus- induced injury in mice by inhibiting inflammatory cell responses and suppressing overproduction of NO in the lung.

In the present study, coincubation of PAMs with the 14membered ring macrolides, erythromycin and clarithromycin, and the 16-membered ring macrolide, josamycin, inhibited the expression of type II NOS mRNA induced by LPS plus IFN- $\gamma$, and the resultant release of NO into the incubation medium. Conversely, amoxycillin and cefaclor, the penicillin and cephalosporin antibiotics, respectively, had no such effects even at high concentration. Thus, the inhibitory effects of antibiotics on the NO-generating system appear to be specific to the macrolides. Moreover, the potency of the inhibition of type II NOS gene expression and NO release was not different between macrolides, suggesting that these drugs possess suppressive actions against NO production regardless of the structure of the lactone ring.

The subcellular mechanism of macrolide action on type II NOS gene expression remains unknown. Recent studies indicate that nuclear factor- $\kappa \mathrm{B}(\mathrm{NF}-\kappa \mathrm{B})$ is one of the most important nuclear proteins involved in the cytokine-induced transcriptional induction of the type II NOS gene in various cell types including macrophages [37, 38], and that promoter regions of the rat type II NOS gene contain NF$\kappa B$-binding sites [39]. Thus, further studies are required to determine whether NF- $\mathrm{KB}$ is the target molecule for mac-rolides in the signal transduction pathway.

In conclusion, the expression of type II NO synthase messenger ribonucleic acid was assessed and the NO release from rat pulmonary alveolar macrophages directly measured, and it was found that macrolide antibiotics inhibited type II NO synthase gene expression and the consequent production of NO induced by lipopolysaccharide plus interferon gamma. Therefore, the inhibitory actions of macrolides on the NO-generating system might reflect the efficacy of the drugs in the treatment of airway inflammatory diseases. However, it is also possible that the reduced NO generation could be detrimental to an important host defence in the lung [40].

\begin{abstract}
Acknowledgements. The authors thank M. Shino and Y. Sugimura for their technical assistance. They also thank Taisho Pharmaceutical Co. and Yamanouchi Pharmaceutical Co. for providing clarithromycin and josamycin, respectively.
\end{abstract}

\section{References}

1. Nathan C. Nitric oxide as a secretory product of mammalian cells. FASEB $J$ 1992; 6: 3051-3064.

2. Försterman U, Schmidt HHHW, Pollack JS, et al. Isoforms of nitric oxide synthase: characterization and purification from different cell types. Biochem Pharmacol 1991; 42: 1849-1857.

3. Gaston B, Drazen JM, Loscalzo J, Stamler JA. The biology of nitrogen oxides in the airways. Am J Respir Crit Care Med 1994; 149: 538-551.

4. Wink DA, Hanbauer I, Krishna MC, DeGraff W, Gamson J, Mitchell JB. Nitric oxide protects against cellular damage and cytotoxicity from reactive oxygen species. Proc Natl Acad Sci USA 1993; 90: 9813-9817. 
5. Granger DN, Kubes P. Nitric oxide as antiinflammatory agent. Methods Enzymol 1996; 269: 434-442.

6. Stamler JS, Singel DJ, Loscalzo J. Biochemistry of nitric oxide and its redox-activated forms. Science 1992; 258: 1898-1902.

7. Kooy NW, Royall JA, Ye YZ, Kelly DR, Beckman JS Evidence for in vivo peroxynitrite production in human acute lung injury. Am J Respir Crit Care Med 1995; 151: $1250-1254$.

8. Kobzik L, Bredt DS, Lowenstein CJ, et al. Nitric oxide synthase in human and rat lung: immunocytochemical and histochemical localization. Am J Respir Cell Mol Biol 1993; 9: 371-377.

9. Persson MG, Zetterstrom O, Agrenius V, Ihre E, Gustafsson LE. Single-breath nitric oxide measurements in asthmatic patients and smokers. Lancet 1994; 343: 146147.

10. Maziak W, Loukides S, Culpitt S, Sullivan P, Kharitonov SA, Barnes PJ. Exhaled nitric oxide in chronic obstructive pulmonary disease. Am J Respir Crit Care Med 1998; 157: 998-1002.

11. Kharitonov SA, Wells AU, O'Connor BJ, et al. Elevated levels of exhaled nitric oxide in bronchiectasis. $\mathrm{Am} \mathrm{J}$ Respir Crit Care Med 1995; 151: 1889-1893.

12. Tamaoki J, Takeyama K, Tagaya E, Konno K. Effect of clarithromycin on sputum production and its rheological properties in chronic respiratory infections. Antimicrob Agents Chemother 1995; 39: 1688-1690.

13. Kadota J, Sakito O, Kohno S, et al. A mechanism of erythromycin treatment in patients with diffuse panbronchiolitis. Am Rev Respir Dis 1993; 147: 153-159.

14. Goswami SK, Kivity S, Marom Z. Erythromycin inhibits respiratory glycoconjugate secretion from human airways in vitro. Am Rev Respir Dis 1990; 141: 72-78.

15. Tamaoki J, Tagaya E, Sakai A, Konno K. Effects of macrolide antibiotics on neurally mediated contraction of human isolated bronchus. J Allergy Clin Immunol 1995; 95: 853-859.

16. Ichimori $\mathrm{K}$, Ishida $\mathrm{H}$, Fukahori $\mathrm{M}$, Nakazawa $\mathrm{H}$, Murakami E. Practical nitric oxide measurement employing a nitric oxide-selective electrode. Rev Sci Instrum 1994; 65: $1-5$.

17. Ignarro LJ, Lippton $\mathrm{H}$, Edwards JC, et al. Mechanism of vascular smooth muscle relaxation by organic nitrates, nitrites, nitroprusside and nitric oxide: evidence for the involvement of $S$-nitrothiols as active intermediates. $J$ Pharmacol Exp Ther 1981; 218: 739-749.

18. Xie QW, Cho HJ, Calaycay J, et al. Cloning and characterization of inducible nitric oxide synthase from mouse macrophages. Science 1992; 256: 225-258.

19. Nunokawa Y, Ishida N, Tanaka S. Cloning of inducible nitric oxide synthase in rat vascular smooth muscle cells. Biochem Biophys Res Commun 1993; 191: 89-94.

20. Misko TP, Moore WM, Kasten TP, et al. Selective inhibition of inducible nitric oxide synthase by aminoguanidine. Eur J Pharmacol 1993; 233: 119-125.

21. Koide M, Kawahara Y, Tsuda T, Yokoyama M. Cytokineinduced expression of an inducible type of nitric oxide synthase gene in cultured vascular smooth muscle cells. FEBS Lett 1993; 318: 213-217.

22. Fariver RS, Brecher P. Salicylate is a transcriptional inhibitor of the inducible nitric oxide synthase in cultured cardiac fibroblasts. J Biol Chem 1996; 271: 3158531592.

23. Moncada S, Palmer RMJ, Higgs EA. Nitric oxide: physiology, pathophysiology, and pharmacology. Pharmacol Rev 1991; 43: 109-142.
24. Guo J-P, Murohara T, Buerke M, Scalia R, Lefer AM. Direct measurement of nitric oxide release from vascular endothelial cells. J Appl Physiol 1996; 81: 774-779.

25. Jorens PG, Van Overveld FJ, Bult H, Vermeire PA, Herman AG. L-Arginine dependent production of nitrogen oxides by rat pulmonary macrophages. Eur J Pharmacol 1991; 200: 205-209.

26. Denis M. Tumor necrosis factor and granulocyte macrophage colony-stimulating factor stimulate human macrophages to restrict growth of Mycobacterium avium and to kill avirulent $M$. avium: killing effector mechanism depends on the generation of reactive nitrogen intermediates. J Leukocyte Biol 1991; 49: 380-387.

27. Padgett EL, Pruett SB. Evaluation of nitrite production by human monocyte-derived macrophages. Biochem Biophys Res Commun 1992; 186: 775-781.

28. Schneemann M, Schoeden G, Hofer S, Blau N, Guerrero L, Schaffner A. Nitric oxide synthase is not a constituent of the antimicrobial armature of human mononuclear phagocytes. J Infect Dis 1993; 167: 1358-1363.

29. Tracey WR, Xue C, Klinghofer V, et al. Immunochemical detection of inducible NO synthase in human lung. $A m J$ Physiol 1994; 266: L722-L727.

30. Nicholson S, Bonecini-Almeida M, Silva JRL, et al. Inducible nitric oxide synthase in pulmonary alveolar macrophages from patients with tuberculosis. J Exp Med 1996; 183: 2293-2302.

31. Tamaoki J, Nakata J, Tagaya E, Konno K. Effects of roxithromycin and erythromycin on interleukin 8-induced neutrophil recruitment and goblet cell secretion in guinea pig tracheas. Antimicrob Agents Chemother 1996; 40: $1726-1728$.

32. Anderson R, Theron AJ, Feldman C. Membrane-stabilizing, anti-inflammatory interactions of macrolides with human neutrophils. Inflammation 1996; 20: 693-705.

33. Chen B, Jiang L, Zhao W, Yu R, Hou XM. Ameliorating effect of erythromycin on bleomycin-induced pulmonary fibrosis: role of alveolar macrophage activation and cytokine release. Respirology 1997; 2: 151-155.

34. Khair OA, Devalia JL, Abdelaziz MM, Sapsford RJ, Davies RJ. Effect of erythromycin on Haemophilus influenzae endotoxin-induced release of IL-6, IL-8 and sICAM-1 by cultured human bronchial epithelial cells. Eur Respir J 1995; 8: 1451-1457.

35. Takizawa H, Desaki M, Ohtoshi T, et al. Erythromycin and clarithromycin attenuate cytokine-induced endothelin-1 expression in human bronchial epithelial cells. Eur Respir J 1998; 12: 57-63.

36. Sato K, Suga M, Akaike T, et al. Therapeutic effect of erythromycin on influenza virus-induced lung injury in mice. Am J Respir Crit Care Med 1998; 157: 853-857.

37. Oddis CV, Finkel MS. NF- $\kappa B$ and GTP cyclohydrolase regulate cytokine-induced nitric oxide production by cardiac myocytes. Am J Physiol 1996; 270: H1864-H1868.

38. Bogdan C, Werner E, Stenger C, Wachter H, Rollinghoff M, Felmayer W. 2,4 Diamino-6-hydroxy pyrimidine, an inhibitor of tetrahydrobiopterin synthesis, down regulates the expression of iNOS protein and mRNA in primary murine macrophages. FEBS Lett 1995; 363: 69-74.

39. Beck K-F, Sterzel RB. Cloning and sequencing of the proximal promoter of the rat iNOS gene: activation of $\mathrm{NF}-\kappa \mathrm{B}$ is not sufficient for transcription of the iNOS gene in rat mesangial cells. FEBS Lett 1996; 394: 263-267.

40. Wink DA, Hanbauer I, Krishna MC, DeGraff W, Gamson J, Mitchell JB. Nitric oxide protects against cellular damage and cytotoxicity from reactive oxygen species. Proc Natl Acad Sci USA 1993; 90: 9813-9817. 